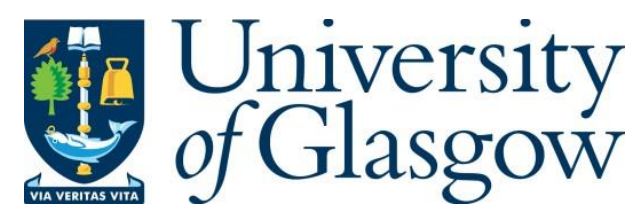

Green, A. (2018) Revolutionary songs in a gentrifying city: stylistic change and the economics of salvage in Southern Mexico. Popular Music, 37(3), pp. 351-370.

There may be differences between this version and the published version. You are advised to consult the publisher's version if you wish to cite from it.

http://eprints.gla.ac.uk/159705/

Deposited on: 29 March 2018

Enlighten - Research publications by members of the University of Glasgow http://eprints.gla.ac.uk 


\title{
Revolutionary Songs in a Gentrifying City: Stylistic Change and the Economics of Salvage in
}

\section{Southern Mexico}

\begin{abstract}
In this article, I explore the case of a musician performing revolutionary songs in a restaurant in a town in southern Mexico undergoing rapid gentrification. I draw out the constraints and possibilities for musical creative agency that emerged in a setting in which commercial activity was driven by the accumulation of profit and rent. Here, commercial strategy could be seen to influence close musical detail; yet such stylistic changes were accentuated by these songs' connection to a movement committed to the end of capitalism. Nonetheless, I draw on the recent work of Anna Tsing to argue that recognizing the incompleteness of revolutionary songs' translation into the rapidly gentrifying context of San Cristóbal may help to underline performer agency and creativity.
\end{abstract}

During recent field research in San Cristóbal de Las Casas, a city in southern Mexico with a large tourist economy, I encountered a number of musicians who were concerned with the effects of gentrification on their creative practice. One, a reggae soundsystem artist, compared the economic trajectory of San Cristóbal to that of Brooklyn and Berlin, in which public spaces become "whitewashed" and local musics were sidelined. ${ }^{1}$ Another, who had been performing in the street in the city for several years, associated the emergence of "increasingly fancy restaurants" in the centre with greater restrictions on street performance. ${ }^{2}$ Finally, another street musician believed that the "capitalist system" had "placed music in an overly narrow structure, in which commercial music predominates", disenfranchising "the music of the world":

Inside [restaurants and bars], you have to play commercial music which 90 percent [of musicians] don't like to play, and they play it just for the money. Outside in the street, you play from the heart, for enjoyment, and because there exists a real interaction among the people that like what you're doing (Joel, 07-08-15)

To spend time with these musicians, then, was to begin to engage with ongoing debates about culture, 
capital, and diversity.

Acute anxieties around the cultural impact of gentrification have, in recent years, made their way into mainstream discourse. The term "gentrification" is linguistically rooted in a particular class of people (the well-mannered "gentry"), and often implies cultural "cleansing" of space (hence, for example, the ironic anti-gentrification slogan "keep Hackney crap!", appropriated from a dismissive statement uttered by a London politician). ${ }^{3}$ In recent years, gentrification has attracted a great deal of media attention, and become the focus of much political mobilization. Geographers have argued that gentrification consists of a process of capital expansion into urban areas, closing "rent gaps" (differences between the value of current and potential rent) by facilitating property development geared towards the middle- and upper-classes, leading to price rises which displace these areas' poorer former inhabitants (Smith 1979: 541-7; Lees et al 2008: 9). This basic formulation has been expanded upon in various ways in the scholarly literature. Thus, gentrification may take various forms, being linked to "the rise of hotel and convention complexes and central-city office developments, as well as the emergence of modern 'trendy' retail and restaurant districts" (Smith and Williams 2013: 3). It often has a racial dimension, tending to displace ethnic minorities (Atkinson and Bridge 2013), and it is, significantly, also associated with the increased regulation of space by the police, deployed to proactively support property prices in gentrifying areas, with police "ceaselessly observing and investigating nuisances until perpetrators are so bothered that they stop" (Pattillo 2013: 332).

Crucially, many anti-gentrification campaigners understand gentrification as a threat to "cultural, social, and economic diversity" in their communities. ${ }^{4}$ For instance, writing in The Telegraph in January 2014, London-based businessman Alex Proud condemned the "Shoreditchification" of London, through which so-called "hipsters" (the contemporary gentrifying classes) gain increasing prominence despite being "all cool by numbers. The people dress the same, they eat the same and the conversations sound the same". ${ }^{5}$ In this sense, then, the gentrification debates rehearse familiar anxieties in which the processual spatial expansion of capital is directly pitted against the heterogeneity of human creativity and identity. Yet, while scholars have engaged with questions to do with capital, music and space (Sterne 1997; DeNora 2000), little research has been carried out into the ways that gentrification relates 
to musical production and performance.

"Gentrification" may be understood as among the most recent in a long list of terms with which anxieties around capitalism and culture have been expressed. Phrases such as "globalization", "cultural imperialism", the notion of the "World System" (Wallerstein 1991) and so-called "McDonaldization" (Ritzer 1983) have all been linked to debates about the relationship between capitalism and cultural diversity. In the study of music, ambivalences have emerged regarding the impact of capital on human creative agency; thus Feld (2000: 146) states that "[m]usical globalization is experienced and narrated as equally celebratory and contentious because everyone can hear equally omnipresent signs of augmented and diminished musical diversity". Taylor (2012) has examined the changing uses of music within the advertising industry in the United States since the 1920s up until the present, when this industry "increasingly drives popular music production" (216-7). This situation, Taylor argues, has both created significant constraints on many musicians' creative labour and threatened musical diversity, forcing compositions into ever-narrower formats (2012: 207-9). Taylor closes his book with the striking image of a Weberian bureaucracy within the advertising industry struggling to impose the "iron cage of rationalization" upon musicians seeking to preserve an “ineffable, mystical, enchanted” form of creativity (245-6). In a similar manner to my consultant Joel, then, Taylor's concerns occupy two broad categories: the effect of capitalist relations on musical style, and the ways that capitalist expansion may promote an instrumental role for music within a system prioritizing financial surplus.

The relationship between musical creativity and commerce has been a particular concern for scholars of popular music. In particular, many of these scholars, often responding to the intellectual legacy of Theodor Adorno, have rejected the notion that capitalism has caused homogenization within the music industries. Thus, Negus provides an overview of popular music scholarship which aligns, in this regards, with the theories of Adorno, yet himself draws upon ethnographic research to argue that record company executives are often at the forefront of stylistic change (1995: 330-1). Krims, meanwhile, uses the example of the "proliferation of new styles and generic hybrids" in 1990s US rap to suggest that, in fact, commercial music in the late twentieth century saw a diversification of musical 
styles as record label ownership consolidated (2003: 136-9). Building on this argument, he calls for scholars to move beyond "monolithic and inflexible models of capitalism" (157). Most recently, Morcom has applied Braudel's "world systems" theory to the example of Tibetan exile pop - a genre which is monetised, but which makes no profit - in order to bring out "capitalism's inherent unevenness or porosity" (2015: 292). While these scholars are concerned with very different contexts for musical creativity, then, each seeks to counter Adornian notions of the progressive commercial standardisation of music.

It is important, therefore, to engage critically with the debates around gentrification from the perspective of music, while attempting to develop nuanced approaches to the relationship between musical production and capital. This endeavour presents us with the challenge of understanding music's relation to capitalism in light of the fact that "music does not sit around exuding commodity status; it has to be commodified, and in ways that are different than other commodities" (Taylor 1997: 283). In turn, considering commodities as a process means that the "intimacy [...] of observational scale" made possible by ethnography may be highly valuable for the study of music and capitalism (Herzfeld 2001: 19). Indeed, it is arguable that the most insightful recent studies on value and exchange have been carried out by economic anthropologists, who treat money as one of a plethora of items used in exchange (Graeber 2001; Wilk and Cliggett 2007). Methodologically, it may be argued, context-specific ethnography constitutes one of the only reliable means through which the challenge laid out above by Krims may be addressed.

One approach which may help to ground debate about value, exchange and culture in heterospecific, everyday experience may be found in the work of anthropologist Anna Tsing. Using the example of the conversion of matsutake mushrooms into commodities, Tsing foregrounds "the openended processes in which historical contingencies are awkwardly woven into capitalism": sorting, classification and spatial separation temporarily convert gifts into commodities for the production of capitalist value (2013: 39). Tsing questions theories that define capitalism as a coherent whole, and positions analysis of the "rough edges" of capitalism - points at which the awkwardness of these processes of conversion becomes apparent - as a crucial task for "ethnographers - observers willing to 
be surprised by details" (38-9). This anthropologist highlights how capitalism is often rooted in what she terms economic "salvage", oriented around the exploitation of "value produced without capitalist control" (2015: 63). This process is dependent on "translation" between different regimes of value creating important roles for well-connected individuals with detailed local knowledge - and is oriented around "pericapitalist" spaces - grey areas at the edge of capitalism (2015: 62). If we wish to understand the operation of capitalist supply chains, she argues, we ought to pay attention to the complex interaction between multiple regimes of value, of which only one is oriented around monetary exchange. Distancing capitalist exchange from production may help us to move beyond monolithic, predictable visions of capitalism as an economic system.

In this article, I explore these themes in relation to nine months of field research in San Cristóbal de Las Casas. ${ }^{6}$ Following Tsing, I argue that this city may be understood as a musical "salvage economy" in which commercial spaces often appropriated, in a temporary and incomplete fashion, musical genres and styles originating in sites with a more distant relationship to capital exchange (2015: 63). Here, the rapid development of the city centre, the accompanying rise in rents, and the impact of commerce on musical expression were concerns for many musicians. Yet, notably, many visitors were attracted by this city's association with revolution, as a key site of pilgrimage for the anti-capitalist, proindigenous rights Zapatista Army of National Liberation (EZLN). Exploring the case of a musician performing pro-EZLN songs in a restaurant in San Cristóbal, I draw out the constraints and possibilities for musical creative agency that emerged in a rapidly gentrifying city in which commercial activity was driven by the accumulation of profit and rents. I argue that a process of gentrification could be perceived to influence music-making in this setting in two key ways, which were highlighted by my consultants: by exerting limits over musical expression in public spaces, and by influencing musical expression within commercial spaces, as musical performance became subordinated to a variety of profit-making strategies. I demonstrate perceptible confluences between commercial strategy and close musical detail, a relationship especially marked by tension given these songs' connection to a movement committed to the end of capitalism. Nonetheless, I argue that the complexities inherent to commercial spaces' appropriation of musical traditions rooted in anti-capitalist social movements are key for 
understanding the creative agency exercised by this article's protagonist.

This article opens with two sections exploring the socio-economic context of San Cristóbal, describing the complex intertwining of revolution, tourism and gentrification that has marked its recent development. It then introduces Hernán, a musician and activist who performed revolutionary songs each week in a local restaurant with ties to the Zapatista movement. In the final two sections, it contextualises stylistic changes that Hernán effected between 2013 and 2016 in relation to the multiple contingencies marking his status as a musical mediator between revolution and commerce.

\section{Gentrification and urban development in San Cristóbal de Las Casas}

San Cristóbal de Las Casas is a city located in the Highlands of Chiapas, Mexico's southernmost and poorest state. San Cristóbal has been defined as a "dual city": historically, the city’s population was dominated by criollos (people of Spanish descent) who inhabited the centre while comparatively small numbers of indigenas (indigenous people) occupied the peripheries (Aubry 2008: 31-5). Such ethnically based spatial separation, reinforced by law during colonial times, was exacerbated in the 1970s and 1980s, when religious conflicts led to a mass exodus of Protestant indigenas from the countryside, forming a "belt of misery" of 20,000 inhabitants in poor neighbourhoods around the city (París Pombo 2000: 91). In the 1980s, just as many outsiders, particularly from Mexico City, moved to the city centre to set up businesses, indigenas from the peripheries began to occupy spaces that had been historically denied to them, such as the cathedral and pavements in the city centre (93). In response, families of coletos (a term used to describe criollos or mestizos from this city [cf. Rocio Bermudez 2011]), some of whom perceived such migration as a threat to their urban "territory", began to leave San Cristóbal (París Pombo 2000: 92-4). For most of its history its population was small, but San Cristóbal became a tourist venue when the construction of the Pan-American Highway in the 1950s connected it to the rest of Mexico. As a result, the city's population expanded from 17,500 inhabitants in 1950 to almost 90,000 in the early 1990s (Berghe 1994: 76-7).

On 1 January 1994, the Zapatista Army of National Liberation (EZLN) launched a rebellion 
across eastern Chiapas. The EZLN was led by a small handful of urbanite guerrillas from large cities, while it was populated mostly by indigenous people from rural Chiapas whose first languages were variously Tzeltal, Tzotzil, Tojolabal, Zoque, Mam and Ch'ol (Barmeyer 2009). Briefly occupying several cities in the state, including San Cristóbal de Las Casas - and accompanied by eye-catching media presentation and critiques of capitalism and neoliberalism - the uprising captured the imagination of leftists across the world, and the Mexican government's decision to agree to a ceasefire on 12 January 1994 has been interpreted by some as a response to a series of pro-Zapatista protests which occurred at an international level (Bob 2005: 128-9). After declaring an offensive ceasefire, the EZLN sought to cultivate a civil movement in Chiapas that would operate without government support, creating a series of organizations of governance to administrate in newly-won Zapatista territory.

San Cristóbal attracted a great deal of government investment in the wake of the Zapatista uprising, which had precipitated an immediate fall in tourism to the city. The Chiapas state government sought to revive the area's tourist sector by pushing for subsidies for tourism in Chiapas and launching marketing campaigns intending to portray Chiapas as a "peaceful and enticing" place (Pitts 1996: 226). But a final part of this move to attract tourism came with later policies encouraging concentrated urban development. After the year 2000 two roads in the centre of the city were pedestrianised, making them particularly attractive hubs for tourist activity (Garza Tovar and Sánchez Crispin 2015: 197-8). These policies were designed to attract both consumers and producers of gentrifying space, and correlated with increased tourism in the city. Between 1991 and 2005, the number of visitors to the city increased by 12 per cent, the second highest increase of any Mexican tourist destination for this period (Propin Frejomil and Sánchez Crespin 2007: 154). My consultants who had spent longest living in San Cristóbal complained that this upsurge had coincided with dramatic increases in rents, especially in the pedestrianised city centre. $^{7}$

In the 1990s, the government's reaction to the Zapatista uprising reinforced in economic terms the spatial marginality indigenas had suffered in previous eras; growing tourism was concentrated in the centre while the mostly indigenous peripheries continued to suffer deep poverty (Garza Tovar and Sánchez Crispin 2015: 205-6). In turn, poor indigenous families were often driven to beg in commercial 
spaces in the city centre (203-5), something to which some businesses responded by repeatedly refusing entry to people in indigenous dress, ${ }^{8}$ implicitly resurrecting colonial patterns of discrimination. The process of gentrification occurring in this city, then, did not simply involve increasing rents, but was also associated with the creation of a normative image of the middle-class, cosmopolitan, light-skinned consumer. ${ }^{9}$ Meanwhile, many shops and restaurants in the city centre (which were often run by people from outside Chiapas and typically owned by a small handful of local landowning $\operatorname{coletos}^{10}$ ) produced a commercialised, generic image of indigeneity in order to appeal to tourists. For instance, a local commercial space called Mexica Tours had an image of the sun on its logo, indexing a generic "indigenous cosmology" oriented around the sun, stars and moon, and avoiding the fact that most of the indigenous languages spoken in the surrounding state were Mayan rather than Mexica. ${ }^{11}$ In the city's square, dancers dressed in feathered costumes presented an exotic vision of pre-Hispanic indigenous identity, before posing for pictures with paying tourists. Here, as in many other contexts, gentrification involved the re-packaging of cultural traditions for wealthy consumers. Indeed, when San Cristóbal was declared a pueblo mágico ("magic town") in 2003, this decision was intended to reflect the cultural richness of the surrounding area, and the concomitant possibilities in the town for developing tourist attractions (Trujillo Correa and López Lecona 2016).

The continued presence of a large number of Zapatista communities in Chiapas has constituted an inspiring symbol for leftists, anarchists and Zapatista sympathisers worldwide, many of whom have travelled to Mexico to visit these communities. Indeed, reflecting on the transnational nature of proEZLN solidarity, Rao argues that the Zapatista movement is highly cosmopolitan (2010: 154). Related to the emergence of this movement, besides coletos and indigenas, in the 1990s and 2000s a new social class of people were attracted to San Cristóbal who were born outside Chiapas, many of whom ran businesses and many of whom were supportive of the Zapatistas. By the time of my research, although it was common to see restaurants and bars displaying Zapatista-themed posters, only a small handful of commercial spaces in the city made an explicit connection to the Zapatista movement, including shop Nemi Zapata, bars Café Bar Revolución and El Paliacate, and restaurant Tierradentro. The influence of the city's new class of cultural cosmopolitans (Turino 2000: 10-12) could be heard every night in 
commercial spaces in the city centre, where transnationally popular genres of music such as ska, rock, pop, salsa, jazz and cumbia crowded out music which was more popular among Mexican audiences, such as boleros and corridos. ${ }^{1213}$

In this setting, commerce was spatially organised according to rent; business owners told me that shops in the best locations on the city's pedestrianised streets could pay several times the rent of an equivalent space located just ten or fifteen metres from these streets. ${ }^{14}$ This reflected the ways that gentrified space in San Cristóbal was both consumed and produced (Lees et al. 2008: 190). Tourists tended to visit the spaces most immediately visible to them, especially in the pedestrianised centre, while spaces further from the centre found it difficult to attract custom. ${ }^{15}$ El Paliacate, for instance, was a bar and "cultural space" hosting an eclectic mixture of music, theatre, and other forms of entertainment which constituted an important locus for the city's small pro-Zapatista activist subculture. Although the owners of this business paid little in rent, their low income made it difficult to pay their performers. The cultural vibrancy of the venue was, therefore, largely a product of the community of mobile and economically independent activists (many of whom would travel to the city for a few months at a time) that frequented it, which included many musicians, such as myself, who were able to perform for free. Local professional musicians, meanwhile, were often unhappy to have amateur performers undercut their income, something which had motivated a recent unsuccessful attempt to agree a collective musicians' minimum wage. ${ }^{16}$

In San Cristóbal, therefore, a number of tendencies worked in conjunction as the centre was gentrified. Rents had been increasing in property for both domestic and commercial use. This was driven simultaneously by a demand for gentrified space among tourists to the city and a push on the part of local government to produce it - most ostensibly by the creation of three pedestrianised streets in the city's centre.

\section{Music, revolution and protest}

Political protest occurred infrequently in public spaces in San Cristóbal's gentrifying historic centre 
during my research. Many among San Cristóbal's pro-Zapatista activist community felt publicly expressing one's political views to be a dangerous activity, since there was a history of government spying on Zapatista supporters in the city (Barmeyer 2009: i-xvii). Public security, meanwhile, had high visibility in the centre, where police officers wore a casual-looking uniform with a t-shirt and baseball cap, tended not to carry firearms, and a comparatively high number were female. In a dynamic common to gentrifying spaces, they therefore both exerted control within public space and conveyed an image of safety for visitors. ${ }^{17}$

This regulation of public space also extended to music. Vargas Cetina describes how, in the late 1990s, groups would often "sing Zapatista corridos with their guitars in the central park" (2000: 74), implying a level of tolerance for the public expression of revolutionary sentiment through music. ${ }^{18}$ By the time of my research, the context for musical expression had changed considerably. Those wishing to perform music in public spaces were now required to gain a permit from the local government in advance, which carried information about their musical style alongside the time and location in which they were permitted to perform. Adherence to the permit was enforced by the local government's inspectors and an extensive police presence in the centre. Songs with political themes were noticeably absent in San Cristóbal's central streets, and there was a perception among some activists that it was not permitted to perform them in this context. One consultant told me that music with political themes was "prohibited by the government, they don't allow, for example, people to be singing the music of the Zapatistas in the street [...] there can even be violence, they can jail them". ${ }^{19}$ Another, who ran a local bar, stated more generally that if musicians set up to play in the street,

they get rid of you. It's about keeping the image clean [...] I think it has to do with the tourist's appreciation rather than making sure that those public spaces are public spaces for the people that live here. (Interview, Chui, 16-10-13)

This consultant, then, perceived a clear connection between present-day patterns of repression in San Cristóbal and the "cleansing" of the city's profile as a tourist destination. While musicians told me stories about police censorship of public performances of political song in the city centre, ${ }^{20} \mathrm{I}$ saw no attempts at street performance of such music during my research - perhaps demonstrating that the 
perception that this might happen had, at least, a chilling effect among some local musicians.

Around the turn of the millennium a series of projects were organised in Zapatista communities aimed at creating products for sale to sympathetic outsiders, including coffee (which one can buy in cities across North America and Europe) and CDs of Zapatista bands. Producciones Radioinsurgente, a Zapatista label whose tagline is "The Official Voice of the EZLN", was created in 2002 to record Zapatista songs - many of which are versions of the corrido genre of song performed by ensembles built around the guitar, vibuela and guitarró $n^{21}$ - in order to disseminate them to the outside world. In the present day, although Producciones Radioinsurgente has ceased to operate, one can purchase copies of these CDs for about fifteen pesos each (about \$1 USD) from a small handful of commercial spaces in San Cristóbal.

Nonetheless, by the time of my research, although San Cristóbal was a hub of pro-Zapatista activity, few pro-Zapatista activists listened to the music produced in Zapatista communities, such as that released on the Producciones Radioinsurgente label. This music was also notably absent from most of the commercial spaces in the city that promulgated a Zapatista image. Among the Zapatista sympathisers in the city, the albums produced by this label seemed to have limited appeal. At one point, a Spanish activist I got to know decided to buy a CD of this music out of curiosity, but reacted negatively when he played it for the first time during a car journey, and switched it off almost immediately. Other activists I spoke to appeared to agree that this music was not made for their consumption; one told me that "it doesn't go with the typical urban taste", while another suggested that urbanite activists and indigenous Zapatistas "live in different aesthetic worlds". ${ }^{22}$ This intriguing comment pointed towards the fact that the songs written and recorded by Zapatista bands tended to break with the expectations of the typical cosmopolitan listener: typically sung loudly with a nasal voice and little dynamic variation, they frequently deployed uneven metrical patterns and used varied rhythmic structures that created ambiguities regarding the relationship between the melody and rhythmic accompaniment. Of the four people I spoke to who did own collections of Zapatista songs, all but one worked for independent media organizations, where they would use these songs in their radio programmes: as an aural signature, as a means to "create atmosphere", to accompany particular 
narratives, or as a means of calling the attention of a particular audience. ${ }^{23}$ This use, it should be noted, diverged from the explicit aim of many Zapatista groups participating in Producciones Radioinsurgente to spread political messages, narratives and information about the Zapatista movement in their music.

Since, as mentioned, this city's "historic centre" had undergone a process of gentrification which involved increasing control over public spaces, using music to spread political messages in this context often required engagement with capitalist arrangements. Furthermore, insofar as the proZapatista activist community local to the city was highly mobile, comparatively wealthy, and cosmopolitan (cf. Rao, 2010), they had much in common with gentrifying classes in many contexts; this picture includes, as suggested above, the fact that they had very different musical dispositions to those of most indigenous Zapatista performers. However, the Zapatista movement had a long history of opposing capitalism that created tensions for pro-Zapatista activists perceived to be complicit in this mode of social organization. This history went back to EZLN figurehead Subcomandante Marcos' communiqué "The Southeast in Two Winds", which was written in 1992 and made public shortly after the 1994 uprising (Subcomandante Marcos 1995: 31-51), ${ }^{24}$ but the Zapatistas had also critiqued capitalism in the Sixth Declaration of the Lacandón Jungle, positioning it as a system based on "exploitation of the workers" and "plunder" of natural resources which "imprisons and kills those who rebel against injustice" and "makes commodities of people, of nature, of culture, of history, of conscience" (EZLN 2005). More recently, in an address given in 2008, Marcos denounced individuals seeking material gain from pro-Zapatista activism, singling out "politicians, intellectuals, artists and people from social movements" who "present themselves as emissaries of the EZLN" and from that gain "political capital" (EZLN 2008). As he paid critical attention to the EZLN's supporters, Marcos fomented internal suspicion among them. In turn, this opened possibilities for tensions to arise in the act of supporting Zapatismo ${ }^{25}$ in San Cristóbal, where pro-Zapatista activists often had little choice but to engage, whether directly or vicariously, in the process of gentrification that was taking place. 
In San Cristóbal, I conducted in-depth ethnographic research with one singer, called Hernán, playing concerts of Zapatista songs and political song from elsewhere in Latin America in local commercial spaces. Hernán was in his early thirties and came from a Tojolabal-speaking family living close to Comitán, a city in south-east Chiapas. Since he himself did not speak Tojolabal, Hernán defined himself as campesino ("peasant") rather than indigenous. At the time of writing, he lived on the outskirts of San Cristóbal, where he had lived since arriving in the mid-1990s to study at a preparatory school. In the city, Hernán had briefly found work at a museum, as well as studying law at a local university in the city in the early 2000s. This diversity of experience was reflected in the genres of music he had grown accustomed to throughout his life. While he had been raised in the countryside listening to norteña and ranchera music, as well as boleros and corridos - that is, songs "to drink to, about women, about love and heartbreak", which the singer called "Mexican songs"26 - Hernán became familiar with genres of music with more middle-class connotations in San Cristóbal. In this urban setting, he had been introduced to the work of nueva trova singers such as Pablo Milanés and Silvio Rodríguez and nueva canción artists such as Alí Primera by a fellow worker at Na Bolom, who also taught him basic guitar-playing technique; he categorised these genres of song as "Latin American music". ${ }^{27}$ The singer described how he had become familiar with nueva trova as part of a wider process of political education (he mentioned reading Eduardo Galeano's book Las venas abiertas de América Latina [1971]), and encountered the music of singers from Central and South America before that of nueva trova singers from Mexico such as Oscar Chávez (indeed, Hernán had become a supporter of the Zapatista movement after listening to Chávez’s 1999 album Chiapas). Thus, although Hernán had an indigenous background, many of his most important musical influences were transnational and cosmopolitan. At the time of research, as well as making money by performing music in several local restaurants - including several nights a week in a venue called Tierradentro discussed in detail below - Hernán gave classes in law at a local university, and was generally a well-respected figure within San Cristóbal's activist community. While he was a solo artist Hernán often performed with accompaniment, and when I arrived in San Cristobal in May 2013 he had been playing for three months with Rigo, a teenage Tzeltal-speaking guitarist from a small town in rural Chiapas named Taniperla, who had recently migrated to San Cristóbal. ${ }^{28}$ 
Although he claimed never to have had singing lessons, Hernán's vocal production was from the diaphragm and his tenor voice full of vibrato, with a large dynamic range. His vocal style, then, recalled singers of nueva canción and nueva trova, while his guitar playing was elaborate, incorporating techniques imported from flamenco such as rasgueando and tremolo playing. Hernán's live performances mostly featured two categories of song. The first were popular songs of love and heartbreak in the bolero or ranchero style. The second was a series of nueva canción and nueva trova songs that altogether formed a narrative of popular struggle across Latin America (Fairley 1984). For example, Hernán often sang Violeta Parra’s “Gracias a la vida”, José de Molina’s “Ya comenzó” and Alí Primera’s “No basta rezar”, as well as Oscar Chavéz’s "Se vende mi país" ("My Country Is Being Sold”). Occasionally, he invented or changed lyrics to these songs in order to link them to the local political context. For example, the singer regularly played Carlos Puebla's "Hasta siempre Comandante", an ode to Ché Guevara often sung in pro-Zapatista activist circles which generally concludes: "Y con Fidel te decimos/Hasta siempre, Comandante" (“And with Fidel we say/Until forever, Commander”). Hernán, however, would often replace the word "Fidel" with figures or locations related to the Zapatista uprising, such as "Chiapas" or (Subcomandante) "Marcos". As well as nueva canción, the singer regularly sang corridos about Emiliano Zapata, the rebel leader in the Mexican Revolution that the term "Zapatista" refers to: thus linking present-day struggles across Latin America within one of the past. "Corrido de la muerte de Zapata" and "Mi general Zapata" eulogise Zapata, a "blessed son of the people" who died "for land and liberty".

Equally, several of the songs that Hernán regularly sang had direct thematic links to the Chiapas conflict, such as "Himno Zapatista" (Zapatista Hymn) - a corrido based on a song about the Mexican Revolution (1910-20) which has come to constitute the main anthem of contemporary Zapatismo which Hernán performed in almost every concert he gave, and often dedicated "to the Zapatista caracoles [cultural centres]" or "to the Zapatista women". ${ }^{29}$ Others included Oscar Chavez's "Siempre me alcanza la danza" ("The dance always gets to me") and "Cuando pienso en Chiapas" ("When I think of Chiapas"), songs that contradict the sanitised image of Chiapas promoted by the government after 1994, describing the state as a place where people "die of hunger in the streets", while "the coletos spend 
their time protecting their wealth". In addition, Hernán often performed "Ya comenzó" (This already began), an upbeat song written by José de Molina in response to the Chiapas conflict, whose lyrics praise the courage of the Zapatista fighters and signal the inevitability and righteousness of the revolution:

El Zapatismo, señores

A la larga ha de triunfar

Porque es una lucha justa

De liberación nacional

Porque esto ya comenzó

Y nadie lo va a parar

(José de Molina, "Ya comenzó”)
Zapatismo, gentlemen

Eventually will triumph

Because it is a just struggle

For national liberation

Because this already started

And no-one's going to stop it

For Hernán, much of the value of "Ya comenzó" was communicative; it addressed a message telling of "what's happening", inviting a broad audience of Mexican society to stand in solidarity with Zapatismo: "labourers, $[\ldots]$ the proletarian man, the students, full-time employees, unsalaried women". ${ }^{30}$

Hernán emphasised the importance of "disseminating” (difundiendo) Zapatismo, thus contributing to what he perceived as one of the most important tasks "that the compas [Zapatistas] are carrying out right now" ${ }^{31}$ In particular, he sought to "carry a message to the people" which could, in turn, play a role in "awakening":

It's the political message that awakens me ... I want to be a participant in that awakening of everyone else. In other words, I don't want to see them live asleep, and die without understanding what had happened.

(Hernán, 09-07-13)

For the singer, "awakening hearts" through transmitting messages in songs constituted "a form of doing politics from below". ${ }^{32}$

Hernán frequently acted strategically in order to achieve his goal of message "transmission" to as broad an audience as possible, and often performed at rallies and political events across Chiapas, as well as commercial spaces in San Cristóbal. Soon after I first got to know him, Hernán invited me to accompany him and Rigo to a primary school located about an hour's drive from San Cristobal at 
which the pair had been invited to perform at a celebration of Día de las Madres (“Mother's Day").

The pair arrived and sang the "Mañanitas", a song performed in Mexico on the occasion of a birthday, after which they received a warm round of applause. Then, after a series of numbers by other contributors, Hernán and Rigo returned to sing a few more songs. Notably, the first was "Corrido de la muerte de Zapata" ("Corrido of the Death of Zapata"), a song recounting the betrayal and assassination of the revolutionary leader. Although Hernán dedicated the song to his maternal grandmother, introducing it as "a sad song, but one of history [...] about the heroes of our Fatherland [Patria]", this corrido was out-of-place in Hernán and Rigo's set, which was dominated by boleros containing themes of love and heartbreak. During our journey back to San Cristóbal, I asked Hernán about his decision to sing "Corrido de la muerte de Zapata". In response, he commented abstrusely that he had used "a small dose, an exact dose" (una dosis pequeña, una dosis exacta), deploying a medical metaphor that simultaneously painted himself as knowing doctor doing what was best for his audience and suggested a strategy of compromise, in which the singer communicated political messages in small, innocuous measures while otherwise fulfilling audience expectations.

Hernán's performances, at this time, strongly reflected the thematic and commercial priorities of the venue in which he performed. Tierradentro was an upmarket restaurant and "cultural space" located in the centre of San Cristóbal which had opened in 2006. Its menu catered to an international palate and its spacious interior was decorated with a number of large plants, wicker lampshades, and a few scattered red stars hanging on wires from the high ceiling. Visitors to Tierradentro could have little doubt about where it situated itself politically. Its walls were covered with Zapatista-themed art, and posters with pro-Zapatista slogans adorned the walls, demanding "no more hostilities against Zapatista communities!" and declaring solidarity with the Zapatistas "[y]esterday, today and forever". In addition, Tierradentro provided spaces for three Zapatista women's co-operatives to sell wares produced in Zapatista communities including hand-woven clothes, hand-crafted footwear, and accessories such as books, mugs, aprons, t-shirts, belts, laptop covers, stickers and balaclavas. It also sponsored Rompevientos, an online independent media project providing a voice for social movements and leftist political struggles. The majority of the waiting staff were migrants from rural Chiapas who spoke 
indigenous languages as well as Spanish, and it was common to see them wearing Zapatista-themed tshirts. Nonetheless, the restaurant tended to attract few coletos or indigenas, being frequented instead by a mixture of tourists, NGO workers and academics of leftist political sympathies who were typically from outside Chiapas and middle-aged or older.

This restaurant, therefore, was an exemplary "rough edge" of transition and ambivalence within capitalism (Tsing 2013: 39). Different economies were at play in this space, rentier and profit-making arrangements co-existing with an alternative arrangement geared towards benefiting communities selfdeclared as "anti-capitalist". It was also, however, framed as a revolutionary participant in an economy of attention (Crogan \& Kinsley 2012), acting through the infiltration of commercial space with radical political messages. When I started research, Hernán had already been performing in Tierradentro three or four nights a week for several years, and the manner in which he had come to be hired by this venue illustrated well the ambivalence and "roughness" pertaining to it. In addition to invitations to sing at protests and (occasionally) in Zapatista communities, Hernán had started to play palomazos [“jams”] informal, spontaneous performances - in commercial spaces in San Cristóbal in the mid-2000s. The singer would often perform "Himno Zapatista" at such informal concerts, and claimed to have gained a reputation in the city as "the only person who dared to sing" this song in public. In an interview he recounted how, on one occasion, he arrived at Tierradentro to play a palomazo; after singing "Himno Zapatista", he was approached by a member of staff, who asked him to perform concerts in the space featuring this song. ${ }^{33}$ Tierradentro paid Hernán 300 pesos per concert, and the singer was also paid to perform in other spaces, where his performances often contained less explicitly political material.

It is worth outlining, in more detail, the typical dynamics of this form of palomazo: a type of concert which here constituted, I suggest, the most important point of contact between commercial and non-commercial spaces. Used in this context, the word palomazo referred to an informal concert in a commercial space which, while framed as a gift, carries the expectation of financial remuneration. A musician would enter a restaurant or bar, ask the staff for permission to play a few songs (the staff, upon agreeing to the request, would switch off any incidental music), perform, and pass through the audience with a hat asking for donations. In San Cristóbal, palomazos were especially popular among 
street musicians for several reasons: they allowed musicians to avoid engaging with the police and local government, whose regime of permits in practice gave them few rights; they allowed audiences to be directly and personally targeted; and singing outside could be exhausting. But palomazos could also be interpreted as moments of "sorting"; they allowed local restaurants to categorise musical performances into styles which could or could not contribute to their commercial identity and strategies (cf. Tsing 2013: 39).

In Hernán’s case, playing a palomazo allowed such a process of sorting to occur, after which his performances - the result of a complex process of social interaction and acculturation at the intersection of rural and urban life - could contribute to the commercial strategy pursued in Tierradentro. Equally, this venue also had a political purpose - to "express the struggle", as one worker put it ${ }^{34}$ - within which Hernán’s performances were overtly contextualised. One senior staff member told me that they allowed Hernán to perform there so that he could "communicate his protest through music", and claimed that as a result of this activity "various people have awakened". ${ }^{35}$ Another told me that "the fact that Hernán sings Zapatista music gives us strength [...] that's what we like a lot about him. Because none of the other places allow you to sing revolutionary Zapatista music". ${ }^{36}$

Nonetheless, the revolutionary identity of this venue was contested. Tierradentro declared its support for Zapatismo most unequivocally in its menu, which claimed that the venue's coffee was "of the highest quality ... sown, cultivated and harvested by Zapatistas”. Lower down, this statement concluded that

consuming this coffee $[\ldots]$ allows indigenous peoples to drive forward their own projects in matters of health, education, shelter, justice, democracy, among others, as part of their own autonomy and free self-determination as indigenous peoples.

Perhaps unsurprisingly, however, many San Cristóbal activists were sceptical about the restaurant's intentions. For instance, a French musician who had lived in San Cristóbal for several years, told me of a perception within this community that Tierradentro wanted to "sell the image" of Zapatismo. ${ }^{37}$ Even the restaurant's book of customer feedback revealed a clientele preoccupied by the actual material links between this business and the Zapatista communities. In this book, as well as remarks about the food, 
atmosphere and service, many people chose to include comments supporting the EZLN (such as "long live the EZLN!" and "long live the liberty of the people!") that implicitly recognised Tierradentro as its legitimate representative. A few comments, however, contested the restaurant's radical political selfpositioning. One read "Long live the fresapatistas!", satirizing the space's typically wealthy clientele with a pun combining the word zapatista with the word fresa, a term in Mexican slang for "posh". Another commenter stated that the restaurant's food "would taste better if some of these profits went to the Zapatista communities", concluding that "it's not enough to just open the space for them, it would be good if you could support them with something". The indignant responses to this comment (which appeared to have been written by staff) were indicative of the high stakes of this debate for a restaurant whose credibility depended upon being seen to actively support Zapatista communities and organizations: objecting, they asked "who says that all we do is open up the space for them, who?" and "what do you mean, there's no profit given to the [Zapatista] communities?" 38

Indeed, Hernán's own views about Tierradentro were similarly ambivalent. When, in September 2013, the electricity commission cut off the venue's supply over alleged unpaid bills, Hernán suspected foul play, suggesting that the restaurant had been singled out "because of what gets disseminated here" ${ }^{39}$ Nonetheless, in interviews, the singer often sought to distance himself from Tierradentro, suggesting that it merely provided a useful "forum" for him to communicate his messages. He could also be highly critical of the venue, telling me that "business is business, no? And it has an economic purpose [...] I don't know if they're just using the [Zapatista] image or if there's any direct contact with the movement". ${ }^{40}$ The singer, therefore, harboured some criticisms of the venue which reflected both discourses prevalent throughout the local activist community and the uncertainties associated with a commercial context in which important financial transactions were largely hidden from view.

\section{Revolution and rhythm: listening to stylistic change}

Stylistically, the music performed by Hernán and Rigo was very different to that of the Zapatista bands whose songs they adapted. As mentioned, these bands often deployed asymmetrical rhythmic structures, and used the insistently uneven meter characteristic of Mexican waltzes, as well as 
performing loudly with little dynamic variation and singing with a nasal vocal technique. The recordings of these songs made by Producciones Radioinsurgente were almost all performed as live in a studio without a click track, and were often structured in unpredictable ways. Little emphasis was placed on the first beat of a bar, and anacruses were rarely used; correspondingly, lines often varied in length within the same song, meaning that if a verse began on the first beat of a bar, its second line might slip back in the bar, beginning on the second or third beat. By contrast, in 2013, Hernán's renditions of Zapatista songs followed classical Western rhythmic structure in which segments of a given line were incorporated into anacruses, so as to fit each line into four bars and emphasise the first beat of each. At a more detailed level, he played rhythm in an expressive, non-danceable tempo rubato fashion which helped him to perform seriousness and drama in his lyrical delivery, pausing on certain words and accelerating through others.

In turn, this non-danceable style was well-suited to the atmosphere encouraged within Tierradentro. Like the use of music in shopping centres studied by DeNora (2000: 138-46), one could understand Hernán and Rigo's music to drive consumption through affecting the body in certain ways. Senior staff at Tierradentro told me that the restaurant was "for people that want to come to work, come to talk ... this is a peaceful space". ${ }^{41}$ Customers valued Tierradentro's tranquillity and spaciousness, and would go there to read, study, and work, as well as socialise. ${ }^{42}$ It was important that both live and background music be appropriate to the space's desired atmosphere. Staff would not allow performers of "noisy" genres of music - such as rock, for instance - to play in the venue. ${ }^{43}$ Meanwhile, much of the background music played in the restaurant was nueva canción, and the venue's playlist also included artists with even more international reach, such as the Beatles and Manu Chao. Although such music contributed to the intended tranquil ambience, it also appealed to a well-travelled, capital-rich audience of middle- and upper-class “cosmopolitans". Finally, live music also encouraged consumption; during performances, Hernán frequently raised his glass (usually of complementary mezral) to the audience, said "cheers" in an impressive number of global languages, and drank. Performances of Zapatista songs in Tierradentro, then, could be seen to correspond to commercial strategies within this space. Here, as suggested above, music could be ascribed two roles 
reflecting this conflict: (1) a means of creating a profitable atmosphere, attracting a moneyed clientele and encouraging them to stay in the venue, socialise and consume, and (2) a medium for the transmission of political messages. Through the majority of my research, the singer's music suited the value of "tranquillity", to which staff expected music played in the space to conform: by performing with rubato rhythm, Hernán was producing un-danceable music which affected atmosphere more than it provoked physical responses in the hearer; further, the echo resulting from the restaurant's ample interior produced of the singer's music a nebulous sound that occupied space while presenting few unnecessary distractions - thus resembling what Sterne labels acoustic "architecture" (1997: 22-3). As such, the singer's performances allowed audiences freedom to respond to his music as they wished. In these circumstances a disconnection could arise between Hernán’s goal of "awakening” audiences with political messages and the sober reality of audience responses to his music. In a few instances, his solo sets were attended by small groups of politically minded enthusiasts who paid him their full attention, applauded loudly, and requested encores. Nonetheless, on most occasions those present were focused on other things, while enjoying the atmosphere to which the singer's music was contributing. Indeed, after finishing songs Hernán frequently had to pause and say "thank you" in a pointed manner in order to receive applause. During the singer's performances, it appeared that his audiences in Tierradentro tended to talk amongst themselves, and after concerts he often complained that those present had paid him little attention. Part of the problem, he said, was that most of the audience was used to "reggaetón, salsa, rumba [...] pop", and unfamiliar with music addressing serious themes, such as deprivation and injustice, which 'bores them [...] it doesn't excite them, because they're used to noise, they're not used to the message". ${ }^{44}$ In fact, these audiences were difficult to anticipate. I encountered a variety of opinions during conversations with customers in Tierradentro, of whom some valued Hernán's music for the messages it contained, and others who felt that it was inappropriate to perform Zapatista songs in this setting. Yet others with whom I attended his performances simply understood little of what he was singing, and blamed a lack of clarity caused by the strong reverberation of sound in Tierradentro's spacious interior. ${ }^{45}$

At this time, however, the singer discussed the possibility of a change in style with me; 
concerned that his concerts were being ignored by audiences, he expressed an interest in trying a "more energetic [movida]" performance approach. ${ }^{46}$ Upon my return in the summers of 2015 and 2016, it became clear that Hernán had given this desire tangible form; he was now leading a larger group of up to seven musicians, including acoustic and electric guitars, bass, and percussion, with a new hybrid style in which his repertoire, having previously been undergirded by tempo rubato, was now supported by shuffling, asymmetrical cumbia rhythms. A hybrid between a "text-centered" genre of music (trova) and “body-centered” one (cumbia) (Baker 2011: 114), Hernán labelled this style trovicumbia. He called the band Los Compas de Chiapas, and later simply Los Compas - both names which index Zapatismo. ${ }^{47}$ Equally, this band's identity remained strongly tied to Tierradentro; in 2016 Los Compas released an album entitled Son del sur ("Sound of the South") which featured images of murals within the restaurant on the front and back covers.

The new musical direction this band took was hardly tranquil: their concerts demanded attention and got it, frequently motivating members of the audience in the restaurant to stand up and dance to insistent, uneven cumbia rhythms. Performances such as these transformed the space of the restaurant, creating a more fun, celebratory experience. This stylistic change was accompanied by an interesting shift in the rhetoric connecting music to revolution. In addition to awareness-raising messages, members of Los Compas emphasised the political importance of "rhythm". The back cover of Son del sur states that "the urgent revolution of today must begin with rhythm to remain in the hearts which dance the sounds of an abysmal reality". During live performances in Tierradentro, Hernán had begun to give short talks emphasizing the importance of rhythm for achieving political change through music:

After ten years of playing trova [...] that political message [...] didn't come with rhythm, it was a political message that was occasionally tiresome. So we started to mix the rhythms of cumbia [...] and now we sing trovicumbia, living political message through rhythm. (Statement during a performance in August 2016)

Another member of Los Compas de Chiapas characterised their goal as raising "awareness, rhythm and joy". ${ }^{48}$ Suddenly, the affective power of music was recognised alongside the serious "message" that Hernán had previously privileged. 
The process by which this band had emerged was highly revealing. This new ensemble had been built up slowly since I had left Chiapas in November 2013, and now included one of Hernán’s university colleagues as well as another migrant from Taniperla. Those running the restaurant had become unhappy with Hernán’s tendency to invite new musicians to perform without consulting them first - not least because this meant that they were obliged to pay more money for live music.

Nonetheless, this dissatisfaction had also extended to musical style. One waiter told me that the staff at Tierradentro had initially disliked the band's sound, feeling that it clashed with the aesthetic priorities of the space. Nonetheless, upon seeing the larger, more enthusiastic audiences Los Compas tended to attract, they had grudgingly accepted that this change was good for business. ${ }^{49}$ Of course, the fact that this creative decision was perceived, among those running the restaurant, as an ongoing act of defiance highlighted a presupposition concerning music's subordination to commercial strategy in this context. In going against the wishes of the restaurant, Hernán exploited his status as the "only person who dared to sing" "Himno Zapatista" in the city, something which afforded him particular agency in a restaurant whose commercial identity was highly reliant on Zapatismo.

\section{Final remarks: On musical salvage}

The challenge that this narrative presents, I suggest, is that of contextualizing the creative agency clearly exercised by the protagonists of this article in relation to a complex set of capitalist relations in a setting marked by gentrification. I began by highlighting the value of the recent work of Anna Tsing in finding pockets of diversity and unpredictability within settings dominated by capital exchange. This work, I suggest here, can be usefully deployed to understand this musical scene, and understand music's relation to the broader process of gentrification occurring in San Cristóbal.

Hernán's performances in Tierradentro may be understood as acts of musical "salvage". That is, he took songs originating outside of capitalism and appropriated them for a commercial space participating, in however ambivalent a manner, in a process of gentrification. For instance, "Himno Zapatista" was written at a Zapatista military training camp in the 1980s, and based on a corrido about 
the Mexican Revolution of 1910-20. By the time of my research, this song had become a key part of Zapatista ritual life, often featuring at encounters and protests. Hernán and his musical collaborators were often invited to perform at such protests and encounters. "Himno Zapatista" had accumulated meaning, then, through being performed at events with a distant relation to capitalism, many of which took place in Zapatista autonomous communities. In turn, protests were open events at which music was performed as a gift to be incorporated within a shared ritual life. Most importantly, they occurred in spaces in which, since no rents were charged, there was little imperative to accumulate capital. Spaces for protest could be understood as "pericapitalist" sites which were "simultaneously inside and outside capitalism” (Tsing 2015: 63) - they were often the sites of deep hostility to capitalist economic processes, yet they produced, and attached richness of meaning to, cultural materials which could be adapted for gentrifying spaces.

Hernán thus worked as a "translator", able to adapt performances of these songs to different contexts. Of course, the singer openly identified as a translator in one way - as a communicator of revolutionary messages through music to those unfamiliar with Zapatismo. Nonetheless, this article has argued that, because of the specific exigencies of the gentrifying space in which the singer worked, such an endeavour also implied translating revolutionary songs for commercial space seeking to cultivate a "tranquil" atmosphere. As Tsing argues, "[t]ranslations across sites of difference are capitalism" (2015: 62). In the context studied here, translation facilitated accumulation even when capitalism had little hand in the production of music. On some levels, Hernán's labour of translation implied simplification and the creation of musical uniformity - for instance, maintaining lines of equal length. Indeed, gentrification in this city could be seen as a series of simplifying translations, such as the dancers performing indigeneity in the central square, or the shops whose titles conflated Mayan and Mexica ethnic groups.

Yet - as indicated by Hernán's open defiance of the wishes of the space - the complexities of being a translator afforded the singer a great deal of creative agency. He was able to develop Los Compas within Tierradentro - despite this band's style being ill-suited to the pre-existing commercial strategy of this venue - because of the highly specific nature of his position as a musical mediator 
between Zapatismo and capitalism. He dared to sing "Himno Zapatista" when others would not; he performed at protests and in Zapatista communities, developing individual credibility as an activist; he was an accomplished performer and his singing voice, full of vibrato, held particular appeal for cosmopolitan audiences. This position was characterised by ambivalences - especially among activists anxious about anyone who could be perceived to be profiting from a Zapatista image - but by the same token it presented plenty of creative possibilities.

It was therefore possible, in this setting, to root agency in acts of musical "salvage". The salvaging of revolutionary songs for a commercial context exemplified the ways that "capitalist commodity value is everywhere created through tapping and transforming non-capitalist social relations" (Tsing 2013: 21). Yet this case study also suggests that the peculiar qualities of positions of translation may make them privileged sites for unpredictable musical change. We may understand most about the relationship between gentrification and musical change by paying close attention to the specific social and musical interactions through which such positions are constituted. Such contingency is the terrain of intimate and open-ended practices of listening.

\section{Endnotes}

\footnotetext{
1 Interview, Manik, 11-06-13.

2 Interview, Lalo, 17-08-15.

${ }^{3}$ http://www.uncarved.org/blog/2009/08/keeping-hackney-crap/ (accessed 23-03-16).

${ }^{4}$ http://bangentrification.org/about/ (accessed 06-02-16).

5 Alex Proud, "Why This Shoreditchification of London Must Stop", The Telegraph, 13 January 2014.

${ }^{6}$ I will also refer to this city as San Cristóbal for reasons of brevity.

${ }^{7}$ Interview, Manik, 11-06-13; Interview, Victor, 12-07-13; Interview, Ricardo, 21-06-13; Interview, Fabricio, 16-07-15. Manik told me of a commercial space in the centre that was rented for $\$ 3,500 \mathrm{MXN}$ per month 8 years prior to our interview, and now cost $\$ 17,000 \mathrm{MXN}$ per month.

8 See http://www.proceso.com.mx/?p=357788 (accessed 13-05-15).

${ }_{9}$ The tattooed, dreadlocked appearance of one respondent who ran a business close to the centre selling CDs, t-shirts and posters had led to difficulties with previous landlords which had forced his business to relocate (Interview, Manik, 11-0613).

${ }^{10}$ Interview, Fabricio, 15-07-15; Interview, Ricardo, 21-06-13.

${ }_{11}$ Prior to the invasion of the Spanish, the Mexica ruled what is now most commonly known as the Aztec Empire.

${ }^{12}$ Boleros are a form of slow-tempo song usually accompanied by the guitar, while corridos are a form of epic ballad popular in Mexico.

13 “Lots of Mexicans here are tired of foreign music. They say 'why don't they play Mexican music?”'(Interview, Alicia, 1505-13).
} 
${ }^{14}$ Interview, Manik, 11-06-13; Interview, Ricardo, 21-06-13; Interview, Fabricio, 15-07-15.

15 Interview, Manik, 11-06-13; Interview, Fabricio, 15-07-15.

16 Interview, Victor, 28-05-13; Interview, Oriana, 28-05-13.

17 Although local rules regarding street music were often unclear - and the interests of respective departments of local government differed - in interviews local government officials emphasised the importance of maintaining clean and tranquil streets as a means of attracting tourism to the city's centre. (Interview, Oscar Chávez, 13-07-15; Interview, Aldo, 2207-15.)

${ }^{18}$ It should be noted that this level of tolerance should itself be considered one of the achievements made in the wake of the 1994 uprising; public spaces prior to 1994 were highly guarded, and especially restrictive for indigenous people

(Interview, Paty, 26-08-13).

${ }^{19}$ Interview, JC, 10-07-13.

${ }^{20}$ Interview, Hernán, 22-09-13.

21 The vibuela and guitarrón are both plucked string instruments typically played in mariachi ensembles, the former having five strings and the latter having six.

22 Alejandro, 29-10-13; Rita, 19-10-13.

${ }^{23}$ Interview, Alejandro, 29-10-13; Interview, "Eustakio", 23-10-13.

${ }^{24}$ It should be noted that, since May 2014, Marcos has officially gone under the name "Subcomandante Galeano", after the brutal murder of a Zapatista elder named "Galeano".

25 That is, the set of beliefs associated with the Zapatista movement, including support for indigenous communities worldwide, opposition to capitalism, and support for the creation of so-called "autonomy".

${ }^{26}$ Interview, Hernan, 08-06-13. Note, however, that the bolero in its contemporary form originated in Cuba.

${ }^{27}$ Interview, Hernan, 08-06-13.

${ }^{28}$ Although he played with a red star with the letters "EZLN" stuck onto the front of his guitar, this had been placed there by Hernán. Rigo himself appreciated Zapatista songs as "a reminder of what happened" in Chiapas, stating that the Zapatistas “aren't doing anything wrong, it's for people's good; they aren't fighting and killing people, they're fighting in an oral way" (Interview, Rigo, 28-06-13).

${ }^{29}$ The chorus of "Himno Zapatista" goes: "now the horizon can be seen/Zapatista combatant/will mark the path/for those that come afterwards".

${ }^{30}$ Interview, 24-08-13.

${ }^{31}$ Interview, Hernan, 22-09-13.

32 Interview, Hernan, 09-07-13.

33 Interview, 09-07-13.

${ }^{34}$ Interview, JC, 10-07-13.

35 Interview, JC, 10-07-13.

36 Interview, José, 25-09-13.

${ }^{37}$ Interview, Oriana, 28-05-13.

${ }^{38}$ In reality, this relationship appeared to be complex and continuously subject to change. One of the Zapatista women's cooperatives based in this space left it towards the end of 2013, amid speculation about the deteriorating relationship between the restaurant and the EZLN.

${ }^{39}$ Interview, Hernan, 22-09-13.

${ }^{40}$ Interview, Hernan, 09-07-13.

${ }^{41}$ Interview, José, 25-09-13.

${ }^{42}$ Interview, Steven, 25-07-13; Interview, Clara, 25-07-15; Interview, Juanito and Juanita, 08-07-15; Interview, Alejandro, $12-$ 07-15.

43 Interview, José, 25-09-13.

${ }^{44}$ Interview, Hernán, 09-07-13. Of course, to establish a distinction between "rhythm" and "message" at this point was perhaps to overlook many existing contexts in which these two features of music have been effectively combined for political purposes, or in which "rhythm" alone has taken on political significance (cf. Browning 1995; Treece 2000).

45 Interview, Tamara, 27-07-15; Interview, Daniela, 27-07-15; Interview, Caro, 06-08-15.

46 Interview, Hernan, 09-07-13.

47 While it is often used in Mexico to mean "mate" or "buddy", the term compa is frequently used among Zapatistas and activists to denote a movement insider.

48 Interview, 23-07-15.

${ }^{49}$ Interview, JC, 01-08-16.

\section{Bibliography}


Atkinson, R. \& Bridge, G. 2013. "Globalisation and the New Urban Colonialism.” In The Gentrification Debates, edited by J. Brown-Saracino, 51-61. London: Routledge.

Aubry, Andrés. 2008. San Cristóbal de Las Casas: Su historia urbana, demográfica y monumental, 1528-1990, 2 da edn. San Cristóbal de Las Casas: Editorial Fray Bartolomé de las Casas.

Baker, Geoffrey. 2011. Buena Vista In The Club: Rap, Reggaetón and Revolution in Havana. London: Duke University Press.

Berghe, Pieter. 1994. The Quest for the Other: Ethnic Tourism in San Cristóbal, Mexico. Seattle: University of Washington Press.

Bob, Clifford. 2005. The Marketing of Rebellion: Insurgents, Media, and International Activism. Cambridge: Cambridge University Press.

Browning, B. 1995. Samba: Resistance in motion. Bloomington: Indiana University Press.

Crogan, P., \& Kinsley, S. 2012. "Paying attention: Toward a critique of the attention economy". Culture Machine 13: 1-29.

DeNora, Tia. 2000. Music in Everyday Life. Cambridge: Cambridge University Press.

EZLN. 2005. Sexta Declaración de la Selva Lacandona. http:/ / enlacezapatista.ezln.org.mx/sdsl-en/ (accessed 11-07-14). 
EZLN. 2008. "Platica del Subcomandante Marcos y el Teniente Coronel Moises con los Miembros de la Caravana que Llegaron al Caracol de La Garrucha, August $2^{\text {nd }}$.

http://enlacezapatista.ezln.org.mx/2008/08/02/platica-del-sci-marcos-y-el-tte-coronel-i-moises-conlos-miembros-de-la-caravana-que-llegaron-al-caracol-de-la-garrucha/ (accessed 11-07-14).

Fairley, Jan. 1984. “La Nueva Canción Latinoamericana.” Bulletin of Latin American Research 3(2): 107-15.

Feld, Steven. 2000. "A sweet lullaby for world music.” Public Culture 12(1): 145-171.

Garza Tovar, J.R. \& Sánchez Crispín, A. 2015 “Estructura territorial del turismo en San Cristóbal de Las Casas, Chiapas, México." Cuadernos de Turismo 35: 185-209.

Graeber, David. 2001. Toward an anthropological theory of value: The false coin of our own dreams. New York: Palgrave.

Herzfeld, Michael. 2001. Anthropology: Theoretical Practice in Culture and Society. Oxford: Blackwell.

Krims, Adam. 2003. "Marxist music analysis without Adorno: popular music and urban geography”. In Analyzing Popular Music, edited by A. Moore, 131-57. Cambridge: Cambridge University Press.

Lees, L., Slater, T. \& Wyly, E. 2008. Gentrification. London: Routledge.

Morcom, Anna. 2015. "Locating music in capitalism: a view from exile Tibet”. Popular Music 34(2): 274295.

Negus, Keith. 1995. Where the mystical meets the market: creativity and commerce in the production 
of popular music. The Sociological Review 43(2): 316-341.

París Pombo, M. D. 2000. "Identidades excluyentes en San Cristóbal de Las Casas." Nueva Antropología: Revista de Ciencias Sociales 58: 81-93.

Pattillo, M. 2013. “Avenging Violence With Violence”. In The Gentrification Debates, edited by J. BrownSaracino, 331-6. London: Routledge.

Pitts, W. 1996. “Uprising in Chiapas, Mexico: Zapata Lives - Tourism Falters.” In Tourism, Crime and International Security Issues, edited by Pizam, A. \& Mansfeld, Y., 215-228. Chichester: John Wiley \& Sons.

Propin Frejomil, E. \& Sánchez Crispin, A. 2007. “Tipología de los destinos turísticos preferencialies en México." Cuadernos de Turismo 19: 147-66.

Rao, Rahil. 2010. Third World Protest: Between Home and the World. Oxford: Oxford University Press.

Ritzer, George. 1983. “The 'McDonaldization' of society.” Journal of American Culture 6(1): 100-107.

Rocío Bermúdez, L. 2011. “¿Categoría étnica? ‘Los coletos’ y la designación de procesos de identidad social. San Cristóbal de Las Casas, Chiapas (México).” Boletin AFEHC no. 50.

Smith, Neil. 1979. "Toward a Theory of Gentrification: A Back to the City Movement by Capital, not People." Journal of the American Planning Association 45(4): 538-48.

Smith, Neil. \& Williams, P. 2013. “Alternatives to orthodoxy: invitation to a debate.” In (eds.) Gentrification of the City, edited by Smith, N. \& Williams, P., 1-12. Winchester, MA: Allen \& Unwin. 
Sterne, Jonathan. 1997. "Sounds like the Mall of America: Music and the Architectonics of Commercial Space.” Ethnomusicology 41(1): 22-50.

Taylor, Timothy. 1997. "The commodification of music at the dawn of the era of 'mechanical music". Ethnomusicology 51(2): 281-305.

Taylor, Timothy. 2012. The Sounds of Capitalism: Advertising, Music, and the Conquest of Culture. London: The University of Chicago Press.

Treece, David. 2000. "Rhythm and poetry: politics, aesthetics and popular music in Brazil since 1960". In Cultural Politics in Latin America, edited by Brooksbank Jones, A., \& Munck, R, 29-42. London: Palgrave Macmillan.

Trujillo Correa, Ricardo and Magali López Lecona. 2016. "Pueblos mágicos y posmodernidad: la turistización de la alteridad." In Desafíos para la psicología social comunitaria. Reflexión, acción e investigación de un primer encuentro, edited by Herazo González, K. \& Javiedes Romero, M, 107-30. Mexico City: UNAM.

Tsing, Anna. 2013. "Sorting out commodities: How capitalist value is made through gifts." HAU: Journal of Ethnographic Theory 3(1): 21-43.

Tsing, Anna. 2015. The Mushroom at the End of the World: On the Possibility of Life in Capitalist Ruins. Oxford: Princeton University Press.

Turino, Thomas. 2000. Nationalists, cosmopolitans, and popular music in Zimbabwe. London: The University of Chicago Press. 
Vargas Cetina, G. V. 2000. "Melodías híbridas: música y músicos en San Cristobal de las Casas;

Chiapas." Nueva Antropologia: Revista de Ciencias Sociales 57: 59-78.

Wallerstein, Immanuel. 1991. “The National and the Universal: Can There Be Such a Thing as World Culture?" In Culture, Globalization and the World-System: Contemporary Conditions for the Representation of Identity, edited by A. King, 91-105. London: Macmillan.

Wilk, Richard, and Lisa Cliggett. 2007. Economies and cultures: foundations of economic anthropology, $2^{\text {nd }}$ edn. Boulder: Westview Press. 